\title{
Creating a Competitive Advantage by Developing an Innovative Tool to Assess Suppliers in Agri-Food Complex
}

\author{
Dédina Daniel, Sánová Petra
}

\begin{abstract}
The main aim of this paper is to introduce a new certified applied methodology for Assessing Suppliers in Agri-Food Complex as a tool for company competitiveness. The work is based on the results obtained in the research project NAZV QG60148/2005 funded by the Czech Ministry of Agriculture and on the requirements of agricultural practice. The novelty lies in the use of practices of the worldwide respected GLOBALG.A.P. standard (formerly EUREPGAP) as yet not well known in our country. Based on the practical experience of the authors with the application of food safety standards in the food manufacturing industry and application of GLOBALG. A.P. standard in agricultural primary production, risk and hazard analysis was developed for the product group of fruit and vegetables. Subsequently, a checklist was designed for the implementation of the suppliers' audit. The result is a methodology for food manufacturers based on the identification of sources of risks in primary production, which can threaten food safety. As part of the introduced methodology are proposed methodological criteria for evaluating suppliers of fruit and vegetables, including rating scales and the possibilities of its implementation. Different variations of the introduction of this approach are discussed from the management, time, and financial viewpoints. The use of this procedure in practice aims to reduce the likelihood of hygiene and health hazards of the basic input raw material according to the principles of the certified standards and thus strengthen the competitiveness of a given manufacturer on the market.
\end{abstract}

Keywords: supplier, methodology, assessment, competitiveness, risk analysis, GLOBALG.A.P., agri-food complex, auditing

\section{INTRODUCTION}

Food producers are responsible for food production safety and according to EC Regulation Nos. 178/2002 and 852/2004 they must purchase all food resources and inputs from reliable and proven suppliers. Chemical residues (e.g. from pests, fertilizers and disinfection), as well as microbial contaminants (e.g. bacteria, mould) are the most common threats in raw plant materials. The safety and quality of raw food materials are the key factors that determine the quality of a final product as well as the competitiveness of a food processing company.

A lot of food processing companies in the Czech Republic have implemented certified safety and quality ensuring standards such as HACCP, IFS, BRC, ISO 9001, ISO 22000, all of which require the suppliers' assessment. However, very often this activity does not include the monitoring of the production process of raw materials (e.g. vegetables, fruit, potatoes, mushrooms, etc.) based on risk assessment systems or customer audits and inspections. 
The improvement of the safety and quality of products is a cornerstone of food producers' competitiveness. It is necessary to guarantee safety of the whole food supply chain from the farm to the table to ensure a company will be able to compete and succeed in the food market. Hence we would like introduce a new certified methodology to assess the raw plant material suppliers. The methodology presents an innovative tool for assessment of the suppliers and brings a completely new approach to the assessment of hygiene conditions and prevention of contamination in agriculture. This methodology meets the requirements of EC Regulation Nos. 178/2002 and $852 / 2004$, and increases the competitiveness of food processing enterprises. The methodology is based on the worldwide used GLOBALG.A.P. standard and includes a quality and safety evaluation in subsequent areas: plant production and harvest, postharvest treatment, environment preservation and workers' health, safety and welfare.

\section{THEORETICAL BACKGROUND}

The role of raw materials purchasing and its contribution to company's grow is crucial, due to the dependence of manufacturing companies on external supplies. The lack of supplies could be devastating for the manufacturing company, therefore supplier monitoring has great importance. Supplies purchasing is regarded as being relevant to firms of all sizes, which, in order to respond to the challenges of increasingly competitive markets, have integrated the purchasing function into strategic planning (Park \& Krishnan, 2001).

\subsection{Assessment and selection of suppliers}

Purchasing is not seen as a separate function; instead it is an integral part of running the company (Gadde \& Hakansson, 2001). Purchasing has been elevated to that of a strategic function within many firms in part due to competitive pressures (Pressey, Winklhofer, \& Tzokas, 2009). Large firms are positive about the role that purchasing plays in comparison to smaller firms, who are less positive about the contribution of purchasing to the organisation (Crichton et al., 2003). Some smaller firms will grow to become the large firms; hence adoption of either purchasing or supplier evaluation methods is indisputably beneficial.

Good purchasing calls for an alignment of the objectives of purchasing with the objectives of the organisation requiring a more proactive role in the management of suppliers and their continual evaluation and appraisal (Carr \& Pearson, 1999). Several authors (Chao, Scheuing, \& Ruch, 1993; Wei, Zhang, \& Li, 1997) agreed that quality and on-time delivery are the most important attributes of purchasing performance. Therefore to ensure smooth raw material purchasing it is necessary to select, continuously monitor and assess the suppliers.

Selecting the right suppliers and evaluating their performance has taken on increased importance in recent years due to the complexity of modern buying decisions, changing buyer preferences and the globalization of trade (de Boer, Labro, \& Morlacchi, 2001).

Supplier selection decisions are complicated by the fact that various criteria must be considered in the decision-making process (Choy, Lee, \& Lo, 2002).

Dickson (1966) indicated that cost, quality, and delivery performance were the three most important criteria in supplier selection process. 
With the increasing significance of strategic sourcing and competition of global environment, the approach to traditional criteria has been changed to reflect the new requirements according to the role of suppliers in the supply chain. Evaluation of suppliers requires consideration of supplier practices (managerial, quality and financial, etc.) and supplier capabilities (co-design capabilities, cost reduction capabilities, technical skills, etc.) (Araz \& Ozkarahan, 2007).

Although many methods have been proposed and used for selection and evaluation of suppliers, most of them try to rank the suppliers from the best to the worst or to choice the best supplier among others.

Periodic evaluation of supplier quality is carried out to ensure the meeting of relevant quality standards for all incoming items (Jain, Tiwari, \& Chan, 2004).

In the past the majority of supplier evaluations were conducted on an ad hoc basis at the buyer's discretion. The buyer decision-making practices of small businesses finding that they favour loyalty to a particular supplier as a means of reducing risk and avoiding the necessity to engage in detailed information search (Pressey et al., 2009).

In the supplier selection and evaluation process, it is not always easy to recognize precise rules, but there is, in general, a coherent way to solve the problem. The choice of supplier is then a problem usually solved by subjective criteria, based on personal experiences and beliefs, on the available information and, sometimes, on techniques and algorithms supporting the decision process (Aksoy \& Öztürk, 2011).

In the absence of market-based control mechanisms, the supply exchange could be subject to opportunistic temptations. An accurate rating system can restore competitive pressure within the pool of suppliers by monitoring and comparing the supplier's improvement over time (Toni $\&$ Nassimbeni, 2000).

Several different methods for evaluating supplier performance have appeared in the literature, such as the categorical method, the weighted point method, the cost ratio method and the weighted point method using a performance matrix and AHP (Li, Fun, \& Hung, 1997).

In the food industry it is necessary, besides the common assessment of suppliers criteria, to ensure the safety of purchased raw materials. In the agricultural primary production there are usually not implemented systems based on HACCP, which can prevent mismanagement of potential risks especially in the hygiene and health areas. HACCP based systems stand on risk analysis and periodical internal audits. Therefore the risk oriented auditing could be a smart solution to ensure the product safety.

\subsection{Risk oriented auditing}

There are many risks in raw materials purchasing, which can be avoided by careful selection and evaluation of suppliers. Risks in the supply chain fall into two categories: those associated with product demand (seasonality, volatility) and product supply (capacity limitations, supply disruptions) (Hallikas, Puumalainenb, Vesterinenb, \& Virola, 2005).

According to Chopra and Sodhi (2004) the risk categories include disruptions, delays, systems, forecasts, intellectual property, procurement, receivables, inventories, and capacity, each one of which may have several variations with regard to their source and type of impact. 
In the agri-food complex, there is another group of risks that concerns the safety of input products. These include the risks of physical, chemical and microbiological nature. The risk of a food safety breach (defects affecting health) of raw materials is very important. Impacts of uncontrolled risks can be fatal for business as well as consumers. Around the world a great emphasis is, therefore, placed on the certification which, in one way or another, includes good agricultural practice, good hygiene practice, and good manufacturing practice.

In recent years, certification has become increasingly important for agribusiness. In Germany, for example, the national Quality and Safety (QS) system has already conducted more than 110,000 audits, mainly in the meat industry, covering about $85 \%$ of all German fattening pigs (European Meat Alliance, 2006). According to the (neo-) classical economic model, the buyers are fully informed about all commodities concerned. Some product quality attributes are known before purchase (for example, freshness or appearance) or after consumption (taste or shelf life), credence attributes (like pesticide residuals), in contrast, cannot be judged by the consumer even after inspection and use (Albersmeier, Schulze, Jahn, \& Spiller et al., 2009). It is necessary to provide this kind of information to buyers through the third-party certification, which reduces information asymmetry (Deaton, 2004). To unsure the credibility of labels such as fair trade or organic farming it is crucial to monitor the whole production process and not just examine the final product. Complex monitoring of these processes could be sometimes almost impossible to carry out with regard to the needs of human and financial resources and competencies for such monitoring. Public authorities are not able to cover the whole market and therefore there is a large group of private companies offering these services.

One suitable option for auditing or certification purposes is the GLOBALG.A.P. standard based on HACCP (Hazard Analysis of Critical Control Points) and risk oriented auditing principles.

GLOBALG.A.P. (formerly known as EUREPGAP) is a collective private standard for implementation of generally agreed principles of good agricultural practices. GLOBALG.A.P. is a pre-farm gate standard concerning aspects of food safety, environmental protection, workers' health, safety and welfare, and traceability (GTZ, 2010). GLOBALG.A.P. has gained global relevance and currently is used in more than 80 countries. The standard is especially important for exporters supplying the European market (Henson, Masakure, \& Cranfield, 2011; Will, 2010). It can be implemented in various areas of agriculture production.

The GLOBALG.A.P. standard indicates control points that were identified as risk, and builds on generally known and verified risks in plant or animal production. Control points and compliance criteria with good manufacturing practice referred to in the GLOBALG.AP are based on the known and proven knowledge of non-compliance in agricultural production, with possible negative consequences. These criteria concern the overall systematic safeguarding of production. The compliance criteria are classified are classified in to three groups: Major must, Minor must and Recommendations. The criteria are generally applicable to agricultural business in various branches, with no possibility of individual adjustments. They include the most fundamental requirements for work safety, hygiene, environmental impacts, breeding conditions (welfare), the contagious diseases situations, and the requirements for produce which would be safe in terms of health. 


\section{AIMS AND METHODOLOGY}

The main objective of this paper is to introduce a new tool for enhancing the competitiveness of companies in the food industry by evaluation of the suppliers of raw plant materials. The methodology is driven to provide regulated procedure for evaluation of purchased raw materials and their suppliers, with regard to product safety and sustainable development. The partial objective is to perform a risk analysis to eliminate health and hygiene risks (notably chemical and microbial), design a checklist for assessing the safety levels of primary producers (suppliers) production, design a table of criteria for the overall assessment of the suppliers' attitude, and assessment of the complexity level of the implementation and maintenance of this methodology in the company. The reduction in the risks of input products serves as a prevention of the recall costs, fines/sanctions and other similar costs, and also enhances the reputation of the company. The methodology is based on the author's theoretical and practical experiences with the GLOBALG.A.P. standard in the Czech Republic during the last seven years and linked to the project: Ministry of Agriculture - NAZV 2006-2009 QG 60148 Support of GLOBALG.A.P. implementation in the Czech agriculture, conducted at the Faculty of Economics and Management, CULS Prague. We consider fruits, vegetables, potatoes and mushrooms as raw plant materials entering the food industry for which the introduced methodology was designed, including quality control and assessment of suppliers.

The first step is to carry out a risk analysis to eliminate potential health and hygiene risks. This must be preceded by a hazard analysis, which is derived from our observation of plant raw materials production and processing. We build on our deep knowledge of crop production, maximum residue limits (MRL), microbial contamination and occurrence of most common threats in food as well. The risk analysis is carried out using the Failure Mode and Effects Analysis (FMEA) technique. FMEA technique includes all elements of risk analysis by defining the scope of action through identification of possible types of errors, assessment of severity of the consequences of errors, using techniques to address potential consequences, identify the causes, determination of probability of error occurrence, calculation of "risk number" and requirements to reduce the error occurrence. During the risk analysis each identified hazard, at each stage of food processing procedure, is assigned a certain value of monitored indicators. Each indicator (eg.: risk of intentional contamination of the product or water, heavy metal and chemical residues, breach of expiration dates, inadvertent contamination of products by workers as coliform and other bacteria and communicable diseases, contamination of the product from the polluted environment, etc.) is evaluated on a 10 point scale. The "risk number", indicated by the letter $\mathrm{R}$, is calculated by multiplying the three values of 14 monitored indicators. $\mathbf{R}=\mathbf{K} \times \check{\mathbf{C}} \times \mathbf{S}$ where $\mathrm{K}$ indicates the risk category (severity of consequences in the risk occurrence), $\check{C}=$ frequency (probability) of the risk occurrence, $S$ = reliability (of current control precaution). There are several risks realized from the carried out analysis related to unintentional food product's safety breach as well as intentional contamination. Additionally, the analysis is about potential intentional entry into the production building or storehouse and contamination of products or service water. Risks of unintentional contamination occur more often in the production process. Unintentional biological and chemical contaminations are assessed as the most risky area. 
We designed a checklist to assess the most important areas of plant production related to the suppliers. The checklist includes a structured table and it is based on the GLOBALG.A.P. concept. For each evaluated sector there is a set of questions formulated on the basis of the risk analysis results. The checklist is used in the third-party customers' audit. The audit should be carried out by a person experienced in the field of HACCP in agriculture or the GLOBALG.A.P. Our checklist was consulted with HACCP and GLOBALG.A.P. auditors and several food processors as well and edited by their comments afterwards. The checklist structure was chosen with regards to the potential possibility of adoption of the GLOBALG.A.P. standard by the food processor. In contrast to the GLOBALG.A.P. standard our checklist includes only the hygiene and health hazards and risks. The checklist questions are not assigned a weight of significance, as in the GLOBALG.A.P., however, some points can be cut out regarding to the relevance of each food processing procedure. Additionally, a visual assessment and application of procedures of supply audits according to ISO 19011:2012 is expected.

As a final step we created a table of criteria for the overall assessment of the suppliers' services together with the methodology implementation, demandingness, and its sustainability in the company. The presented innovative tool can be used mainly by processors who have a certified quality management system in place and must verify the activities carried out, which are evaluating the reliability of suppliers in terms of safety of purchased plant raw materials. Possibilities of implementation were discussed with representatives of Czech National Certification Forum (CNCF).

\section{RESULTS}

\subsection{Risk analysis and assessment of suppliers}

The main areas of raw plant materials (vegetables, fruit, potatoes, mushrooms) production where potential risks can occur are the pre-production period, production period, harvest period and after-harvest activities (e.g. washing, packing, etc.)

The pre-production period includes activities related to the site history and site management. It is necessary to consider the purpose for which the land was previously used and identify the risks arising from the land use for agriculture (e.g. land contamination, residues of DDT, etc.). This area also covers propagation material, especially seed treatment. In a broader context, because of lower future use of plant protection products, the appropriateness of a plant variety should be considered in relation to its disease resistance. Fertilizer application presents a potential hazard (e.g. heavy metals, nitrogen content in the soil) during the pre-production period as well as the production period.

The production period area comprises risks related to irrigation and fertilization, application of plant protection products, implementation level of integrated pest management, together with visual inspection and functional tests of application equipment.

The harvest period and post-harvest activities pose risks arising from the level of hygiene of workers, equipment and the working environment (microbiological contamination), together with the use of water (proven source) and postharvest treatment (biocides, wax, etc.).

From the perspective of hazard prevention in agriculture it is necessary to manage residue analysis, MLR exceedance, and traceability. 
The requirements for future supplies must be reviewed while the buyer is assessing the suppliers. Unclear, delayed and/or incomplete requirements defined for the supply of raw materials may cause significant problems. Written determination of requirements should include the following topics:

a) identification of quality attributes and their values (e.g. for fruit sensorial, chemical attributes, or microbiological while fruit is affected by disease, mould, etc.)

b) time validity of attributes value (may slightly vary for different species, storage conditions or planned processing).

c) specified procedures, measurement units and product testing (description of the sampling procedure, sensorial evaluation consecution, frequency and type of laboratory testing on the MLR, heavy metals and nitrates, etc.

d) defined acceptance criteria for supplies (lay down clear limits for taking over of supplies for each kind of fruit - e.g. MLR limits, acceptable number of nonstandard pieces)

e) delivery terms and amounts - specified for each kind of fruit

f) identification of supplies and traceability requirements

\section{g) procedure for the review of the delivery requirements before ordering}

h) expected maximal costs related to the delivery (incl. supplies assessment, take over, washing, cooling, etc.)

As an example of determination of requirements see Table 1, designed for raw material "strawberries".

To carry out an audit at the supplier is the most important, but not the only one step, of the process evaluation and selection of supplier. Each evaluation criteria is assigned a certain number of points according to the importance of the criteria. The total number of points shows the classification of the supplier. There are several different supplier evaluation criteria e.g.: reliability of supplies, quality and safety of products, flexibility and quality of logistic service, price, and communicativeness. The goal is to carry out a checklist based audit at the supplier, with strictly defined good agricultural praxis (GAP), healthy and hygiene requirements based on the risk assessment approach.

Classification of suppliers (e.g.):

$90-100$ pts. = excellent supplier - relationship is based on partnership and strategic cooperation; receives majority of orders

$70-90$ pts. = very good supplier - good cooperation, tendencies for improvement; receives good number of orders, can become an excellent supplier

$50-70$ pts. $=$ average supplier - fulfilling requirements and specifications; receives only certain number of orders, must improve to keep his position or lose it

$>50$ pts. $=$ disqualified supplier - cooperation with him brings additional costs, receives no orders 
Tab. 1 - Requirements for purchased raw material. Source: Mlynář (2009) and self-elaboration.

\begin{tabular}{|c|c|}
\hline \multicolumn{2}{|r|}{ Requirements for purchased raw material } \\
\hline Raw material: Strawberries & Code: JP 258/9 \\
\hline \multicolumn{2}{|c|}{ General description: strawberry fruit - ripe, whole fruit red, permitted a light green tip } \\
\hline \multicolumn{2}{|c|}{ Classification of impurities: } \\
\hline \multicolumn{2}{|c|}{$\begin{array}{l}\text { Class A: NO (glass, metal, stones, bones, insects or parts } \\
\text { contaminants, fragments of hard plastic and wood, etc.) }\end{array}$} \\
\hline \multicolumn{2}{|c|}{$\begin{array}{l}\text { Class B: unacceptable (pieces of rope, string, hair, fragments of soft plastics, rubber, insects or parts of } \\
\text { smaller than } 3 \mathrm{~mm} \text { ) }\end{array}$} \\
\hline \multicolumn{2}{|c|}{ Class C: tolerated in the minimum quantity (plant parts - such as leaves, stems) } \\
\hline \multicolumn{2}{|c|}{ Note: Classification of impurities is based on the risk of their occurrence with respect to buman bealth. } \\
\hline \multicolumn{2}{|c|}{ Organoleptic evaluation: } \\
\hline Appearance & $\begin{array}{l}\text { Fruit - ripe, whole fruit red, permitted a light green tip. Clean. Fresh. No wilted leaves } \\
\text { with, brittle consistency of pulp. } \\
\text { Size-balanced. Size must not drop below } 18 \mathrm{~mm} \text { in diameter and shape must cor- } \\
\text { respond to the variety. Size tolerances: For all quality classes: } 10 \% \text { by number or weight } \\
\text { of strawberries not conforming to the minimum size. No signs of pest and disease. } \\
\text { If not influence overall appearance of purchased supply, slight imperfections are toler- } \\
\text { ated: slight imperfection in shape, whitish colour not exceeding one tenth of the whole } \\
\text { surface, slight bruising on the surface. Almost no soil. } \\
\text { For take over the supply is allowed } 10 \% \text { of inadequate raw material } \\
\text { to requirements mentioned above. Within this tolerance, not more } \\
\text { than } 2 \% \text { of impaired fetuses. }\end{array}$ \\
\hline Flavour / aroma: & $\begin{array}{l}\text { Intensive aroma (note. weakening after } 10 \text { hours). Full flavour with a very mild acid, } \\
\text { the dominant impression of sweetness and significantly fulfilling, typically strawberry. }\end{array}$ \\
\hline Method of testing: & Sensorial: visual examination and tasting \\
\hline Note: & $\begin{array}{l}\text { For the first supply in the year send a sample to an accredited laboratory. See. Procedure } \\
\text { No. } 587 / 08 \text {. }\end{array}$ \\
\hline \multicolumn{2}{|c|}{ Time validity of attributes: during the strawberries season - May 20 to June 30.} \\
\hline \multicolumn{2}{|c|}{$\begin{array}{l}\text { Packaging / Labelling: Paper cartons, wooden boxes of } 3 \mathrm{~kg} \text {. Each delivery will be clearly marked with name and ad- } \\
\text { dress of the supplier, batch number and net weight. Supply attached with a copy of GLOBALG.A.P. certificate if relevant or } \\
\text { at least a certificate of customers' audit. }\end{array}$} \\
\hline \multicolumn{2}{|c|}{$\begin{array}{l}\text { Transport: In the covered, clean and cooled vehicles. The product may be transported together with compatible materials or } \\
\text { foodstuffs. The temperature must be between } 5-10^{\circ} \mathrm{C}\end{array}$} \\
\hline \multicolumn{2}{|c|}{ Storage: Short-term up to 48 hours at a temperature 5 to $10^{\circ} \mathrm{C}$} \\
\hline \multicolumn{2}{|c|}{$\begin{array}{l}\text { Note: Level of nitrates, heavy metals and MRL must comply with legislation of the Czech Republic and } \\
\text { confirmed by any analysis from an accredited laboratory. The laboratory must determine whether the level } \\
\text { of the above factors is within the limits for infant formula. }\end{array}$} \\
\hline $\begin{array}{l}\text { Date + signature of repre- } \\
\text { sentative customers: }\end{array}$ & Date + signature of representative suppliers: \\
\hline
\end{tabular}




\subsection{Designing checklist for assessment of suppliers}

Our methodology for assessment of suppliers (customers' audit) includes 47 control points in prospective of ensuring the raw materials safety. These points include a set of requirements covering different areas of traceability, evidence of correctness of the application of fertilizers and pesticides, producers' membership in SIPSO (Association of Integrated fruit-growing) or IPZ (Association of Integrated vegetables-growing), safety of irrigation water, verification of production safety in terms of chemical residues, and handling of the product during and after harvest (e.g. washing, storing) to keep the product quality attributes and fulfil hygienic requirements. To receive the objective audit results it is necessary to carry out the audit during the harvest season.

Among the important key issues (control points) in the customers' audit belong these topics:

- Does producer maintain clear and up-to-date records about all applications of plant protection products? The records must include information about place and date of application, crop, name of the product, reason of application, method of application, applying device, amount of the plant protection product, protecting period and responsible employee.

- Were the protecting periods respected?

- Was the analysis of health/hygienic risks and risk for dealing with harvest assessment made to fulfil hygienic aspects of dealing with production?

- Did the producer analyze hygiene risks for harvest of crops supplied and for their transportation?

- Is there the evidence that workers were informed about sanitary guidelines and hygiene rules before harvest and manipulation with production?

- Do workers that are in direct contact with crops have the opportunity to wash their hands with soap in clean water? Do workers in fields and gardens have these conditions as well?

- Do personnel wear outwear that is clean and proper for working purposes and able to protect the products from contamination (where it is relevant)?

- Do workers of packaging room have the access to clean lavatory and hand washing facilities close to their workplace? Doors from lavatories must not be opened to the area where the product is manipulated with.

- Are unbreakable light fittings or lamps with protective case used in warehouses, sorting houses and packaging rooms?

- Is entrance of animals to warehouse, sorting house and packaging room prohibited?

- Are there written procedures for manipulating with glass and hard plastics?

- Are packaging materials clean and stored in clean sanitary conditions?

- If postharvest washing is used, is water used in this case drinking water and is the analysis of water made by accredited laboratory?

- etc.

The sets of questions have a spreadsheet form, where for each question there is a fulfilment statement (Yes/No). When the requirement is partially fulfilled, the statement value is No. We recommend including with each checklist a reference box for objective evidence to confirm the auditor's statement (see Tab. 2). Complete methodology is available on request by authors. 
Tab. 2 - Checklist structure example. Source: self-elaboration.

\begin{tabular}{|c|l|c|c|}
\hline Nr. & \multicolumn{1}{|c|}{ Requirement } & $\begin{array}{c}\text { yes/no/ not } \\
\text { relevant } \\
\text { (N/A) }\end{array}$ & $\begin{array}{c}\text { comment / } \\
\text { evidence }\end{array}$ \\
\hline 1 & $\begin{array}{l}\text { Does the producer have the production sites marked? } \\
\text { Does producer have clear and up-to-date records } \\
\text { about agronomic activities for every production site? }\end{array}$ & $\begin{array}{l}\text { Has the producer risk analysis of current and new } \\
\text { agricultural spots (production sites) with regard to } \\
\text { food security? }\end{array}$ & $\begin{array}{l}\text { Does the producer have annual inspection records of } \\
\text { technical device designed for manure application to } \\
\text { assure exact dosage? }\end{array}$ \\
\hline
\end{tabular}

\subsection{Implementation}

For implementation of our methodology it is necessary for a company to consider way of good agricultural practices audit at the supplier. Overall assessment (results of audit together with other important criteria as price, on-time delivery, etc.) might be carried out for example by purchasing director on bases of evidence elaborated by his employees or suppliers.

There are three possible ways of customers' audit at the supplier based on our methodology.

I. Company use its own human resources and selected employees are trained in field of audits/ inspections or GLOBALG.A.P. standard.

II. Company hires new employee with adequate skills and experience in field of audits/inspections or GLOBALG.A.P. standard.

III. Company outsource an audit specialist.

Table 3 presents possibilities for the implementation of introduced methodology in the perspective of time demand, organizational and economical aspects. 
Tab. 3 - Possibilities for the implementation of introduced methodology. Source: self-elaboration.

\begin{tabular}{|c|c|c|c|c|}
\hline Situation & Costs & Advantages & Disadvantages & Deadline \\
\hline $\begin{array}{l}\text { Company will } \\
\text { use its own hu- } \\
\text { man resources } \\
\text { and selected } \\
\text { employees will } \\
\text { be trained in the } \\
\text { field of audits/ } \\
\text { inspections or } \\
\text { GLOBALG. } \\
\text { A.P. standard. }\end{array}$ & $\begin{array}{l}\text { Training / } \\
\text { education fees; } \\
\text { travel costs. }\end{array}$ & $\begin{array}{l}\text { Company knows } \\
\text { its own employ- } \\
\text { ees, low growth } \\
\text { of labor costs. }\end{array}$ & $\begin{array}{c}\text { Poor profes- } \\
\text { sional skills of } \\
\text { own employees } \\
\text { cannot guaran- } \\
\text { tee success of } \\
\text { the audit, lack of } \\
\text { experience can } \\
\text { bring mistakes } \\
\text { in self carried } \\
\text { audits. }\end{array}$ & $\begin{array}{l}\text { Depends on } \\
\text { employees train- } \\
\text { ing time and } \\
\text { negotiation with } \\
\text { service provider. }\end{array}$ \\
\hline $\begin{array}{l}\text { Company } \\
\text { does not have } \\
\text { adequate hu- } \\
\text { man resources } \\
\text { and hires new } \\
\text { employee. }\end{array}$ & $\begin{array}{l}\text { Growth of labor } \\
\text { costs for new } \\
\text { employee (usu- } \\
\text { ally higher then } \\
\text { training/educa- } \\
\text { tion fees for cur- } \\
\text { rent employees) } \\
\text { and travel costs. }\end{array}$ & $\begin{array}{l}\text { Include to } \\
\text { hiring require- } \\
\text { ments sufficient } \\
\text { knowledge in } \\
\text { audits/inspec- } \\
\text { tions, GAP or } \\
\text { GLOBALG. } \\
\text { A.P.; this should } \\
\text { lower number of } \\
\text { mistakes in self } \\
\text { carried audits. }\end{array}$ & $\begin{array}{l}\text { Growth of labor } \\
\text { costs, unfamili- } \\
\text { arity with new } \\
\text { employee (reli- } \\
\text { ability, precise- } \\
\text { ness, etc.). }\end{array}$ & $\begin{array}{l}\text { Depends on hir- } \\
\text { ing time of new } \\
\text { employee and } \\
\text { negotiation with } \\
\text { service provider } \\
\text { (can be shorter } \\
\text { than in the first } \\
\text { option). }\end{array}$ \\
\hline $\begin{array}{l}\text { Company will } \\
\text { outsource an } \\
\text { audit specialist. }\end{array}$ & $\begin{array}{l}\text { Costs are } \\
\text { increased by the } \\
\text { outsource price } \\
\text { (incl. Travel } \\
\text { costs), which } \\
\text { can be lower } \\
\text { than the labor } \\
\text { costs for new } \\
\text { employee. }\end{array}$ & $\begin{array}{l}\text { Through an } \\
\text { invitation to ten- } \\
\text { der the company } \\
\text { can choose the } \\
\text { most experi- } \\
\text { enced partner } \\
\text { within field of } \\
\text { needed require- } \\
\text { ments, what } \\
\text { should eliminate } \\
\text { mistakes in com- } \\
\text { pany self carried } \\
\text { audits. }\end{array}$ & $\begin{array}{l}\text { Increase of serv- } \\
\text { ice costs. }\end{array}$ & $\begin{array}{l}\text { Depends on the } \\
\text { tender time and } \\
\text { other business } \\
\text { negotiations. }\end{array}$ \\
\hline
\end{tabular}

It depends on the management of the company and its economic situation, which of the above described implementation possibilities to choose. During the decision process the company management should assign significance to each criterion. The aim is correctly and well-made assessment, otherwise the implementation of this methodology becomes meaningless and results only in wasted costs incurred. Important role plays the total cost of implementation. Too high 
cost of the implementation may reduce the competitiveness of the company, especially in the first period of implementation. Another important issue is the time factor. The sooner a company ensures the quality of supplies, the better the company avoids potential problems related with risks in raw materials.

Together with assessment of the temperate climate raw plant materials suppliers the company can start to use introduced methodology for sub-tropic and tropic raw plant materials suppliers with the fact that the producers will not carry out its own audits, but will require a guarantee by valid GLOBALG.A.P. standard certificate.

\section{DISCUSSION}

Until now, there has not been an article like this conducted in the Czech Republic in the field of Assessing Suppliers in Agri-Food Complex following the implementation of GLOBALG. A.P. standards and specifying relations between food processing company's competitiveness and proof of ensuring the safety of the purchased raw materials. We discuss implementation possibilities of the introduced tool, in terms of cost demandingness, which depends on the size of the company, number of suppliers and the method of implementation itself. It is important to mention, that because of relevance, importance and probability of various risks together with unique environment in each food processing company, we have designed the checklist's questions with no weight of significance to stimulate the responsible quality managers to adopt own attitude to risk analysis assessment. Implementation of our introduced Tool to Assess Suppliers in AgriFood Complex strengthens the competitiveness of food processing companies. The checklist approach, together with company's self- assessment of its own risk environment, also improves the competitiveness of raw material suppliers.

The first possible implementation solution is to choose an employee among company's own human resources and train him/her in the field of audits/inspections or GLOBALG.A.P. standard. The advantage is that the company knows its employees very well and can quite easily identify the best one for this role. The costs related to training of one person are assumed to be about 20000 CZK annually and will be repeated for about three years. The only suggestion for this solution is to enlarge job description of selected employee to prevent high growth of labor costs and reward the employee with an extra bonus to his current salary. In terms of training time required, one employee needs about 40 hours of education and 12 days of auditor job shadowing. In the beginning, the low experience of the trained employee cannot guarantee success and preciseness of carried audits.

Another possibility is to hire a new employee, who is already skilled, educated and experienced in the field of GLOBALG.A.P. and HACCP audits/inspections. The full-time monthly salary for this specialist is assumed to be 50000-60000 CZK incl. employer's costs (health and social insurance, etc.), which could be excessive for a small or mid-size company. In this case we suggest hiring this specialist only for a part-time job with assumed labor costs being 20000 CZK incl. employer's costs. Hiring a new employee can take up to 6 months, depending on the current situation of the labor market. The advantage of this solution is minimizing the number of mistakes in audits and evaluation due to the specialist's experiences, however, there is certain level of unfamiliarity with the new employee (reliability, preciseness, etc.). 
When a company decides to outsource an audit specialist, the related costs are presented by covering the audit specialist's services, which could be around 12000 CZK for each audit conducted. It is necessary to carry out one audit at each supplier per year. With the rising number of suppliers this solution is becoming more costly and is more suitable for a company with several strategic suppliers cooperating long term. Finding a specialist can take from a few days to several months and using a tender to hire a specialist can help the company choose the most experienced one or select the proper one under the price-quality ratio requirement.

The overall benefit to the company's competitiveness rising from implementation of introduce tool is a precautionary arrangement, which prevents product safety problems and the costs associated with them. These possible costs are in the form of re-calls, fees, sanctions, goodwill disruptions, loose of customers, etc. We assume the money-value of this benefit for a mid-size food processing company is about 2 mil. CZK.

\section{CONCLUSION}

Supplier selection and evaluation is one of the most critical activities of companies, since supply performance can have a direct financial and operational impact on the business (Croom, 2001). Evaluation and selection of suppliers presents a set of activities aimed to select the best supplier, who will be able to fulfil customers' requirements for safety and quality of purchased raw materials. Methodology introduced in this paper can efficiently eliminate health and hygienic risks of Raw Plant Materials used in the food industry, especially in eliminating of chemical risks (e.g. residue limits, including heavy metals and nitrates) and microbial risks (coli-form bacteria, streptococcus etc.). Implementation of this methodology creates a competitive advantage for food processing companies, trough the preventive approach and guarantee of safe products and thus increases the competitiveness of the food industry. This approach should be included in the processes of assessment of suppliers and quality control of supplies. Final decision of the company to implement this methodology is related with the total cost of implementation, time factor and company's attitude. Only superior and correctly made evaluation of suppliers leads to the success. The option for food processing companies could be requiring the GLOBALG.A.P. standard on their suppliers.

\section{References}

1. Aksoy, A., \& Öztürk, N. (2011). Supplier selection and performance evaluation in just-intime production environments. Expert Systems with Applications, 38(5), 6351-6359. http:// dx.doi.org/10.1016/j.eswa.2010.11.104

2. Albersmeier, F., Schulze, H., Jahn, G., \& Spiller, A. (2009). The reliability of third-party certification in the food chain: From checklists to risk-oriented auditing. Food Control, 20(10), 927-935. http://dx.doi.org/10.1016/j.foodcont.2009.01.010

3. Araz, C., \& Ozkarahan, I. (2007). Supplier evaluation and management system for strategic sourcing based on a new multicriteria sorting procedure. International Journal of Production Economics, 106(2), 585-606. http://dx.doi.org/10.1016/j.ijpe.2006.08.008

4. Carr, A. S., \& Pearson, J. N. (1999). Strategically managed buyer-supplier relationships and performance outcomes. Journal of Operations Management, 17(5), 497-519. http://dx.doi. org/10.1016/S0272-6963(99)00007-8 
5. Crichton, C., Gallery, C., Zammit, V., Hughes, J., Vammen, S., \& Day, M. (2003). Collecting purchasing and supplier strategies to shareholder value. Emerging trends for executive action. Future Purchasing Alliance, Retrieved from: http://www.futurepurchasing.com

6. Croom, S. (2001). The dyadic capabilities concept: examining the processes of key supplier involvement in collaborative product development. European Journal of Purchasing and Supply Management, 7(1), 29-37. http://dx.doi.org/10.1016/S0969-7012(00)00019-8

7. De Boer, L., Labro, E., \& Morlacchi, P. (2001). A review of methods supporting supplier selection. European Journal of Purchasing \& Supply Management, 7(2), 75-89. http://dx.doi. org/10.1016/S0969-7012(00)00028-9

8. Deaton, B. J. (2004). A theoretical framework for examining the role of third-party certifiers. Food Control, 15(8), 615-619. http://dx.doi.org/10.1016/j.foodcont.2003.09.007

9. Dickson, G. W. (1966). An analysis of vendor selection systems and decisions. Journal of Purchasing, 2(1), 5-17.

10. European Meat Alliance (EMA) (Eds.) (2006). Safe food transparently produced, Retrieved from: http://www.european-meat-alliance.eu

11. Gadde, L., \& Hakansson, H. (2001). Supply Network Strategies. Chichester: Wiley.

12. GTZ, (2010). GLOBALG.A.P. Smallholder QMS Set-up Guide: How to Establish a QMS in Your Group. Eschborn: Deutsche Gesellschaft für Technische Zusammenarbeit.

13. Hallikas, J., Puumalainenb, K., Vesterinenb, T., \& Virola, V. (2005). Risk-based classification of supplier relationships. Journal of Purchasing \& Supply Management, 11(2-3), $72-$ 82. http://dx.doi.org/10.1016/j.pursup.2005.10.005

14. Henson, S., Masakure, O., \& Cranfield, J. (2011). Do Fresh Produce Exporters in SubSaharan Africa Benefit from GLOBALG.A.P. Certification? World Development, 39 (3), 375386. http://dx.doi.org/10.1016/j.worlddev.2010.06.012

15. Chao, C., Scheuing, E. E., \& Ruch, W. A. (1993). Purchasing performance evaluation: An investigation of different perspectives. International Journal of Purchasing and Materials Management, 29(3), 33-39.

16. Chopra, S., \& Sodhi, M. S., (2004.) Managing risk to avoid supply chain breakdown. MIT Sloan Management Review, 46(1), 53-61.

17. Choy, K. L., Lee, W. B., \& Lo, V. (2002). An intelligent supplier management tool for benchmarking suppliers in outsourcer manufacturing. Expert Systems with Applications, 22(3), 213-224. http://dx.doi.org/10.1016/S0957-4174(01)00055-0

18. Jain, V., Tiwari, M. K., \& Chan, F. T. S. (2004). Evaluation of the supplier performance using an evaluationary fuzzy-based approach. Journal of Manufacturing Technology Management, 15(8), 735-744. http://dx.doi.org/10.1108/17410380410565320

19. Li, C. C., Fun, Y. P., \& Hung, J. S. (1997). A new measure for supplier performance. evaluation. IIE Transactions, 29(9), 753-758. http://dx.doi.org/10.1080/07408179708966385

20. Mlynáŕ, J. (2009). Vzorový postup pro nakupování. Zajištění kvality. Kvalita potravin, 9(2), 19-21.

21. Pressey, A. D., Winklhofer, H. M., \& Tzokas, N. X. (2009). Purchasing practices in smallto medium-sized enterprises: An examination of strategic purchasing adoption, supplier evaluation and supplier capabilities. Journal of Purchasing \& Supply Management, 15(4), 214-226. http://dx.doi.org/10.1016/j.pursup.2009.03.006 
22. Toni, A., \& Nassimbeni, G. (2000). Just-in-time purchasing: An empirical study of operational practices, supplier development and performance. The International Journal of Management Science, 28(6), 631-651.

23. Wei, S., Zhang, J. \& Li, Z. (1997). A supplier selecting system using a neural network, In IEEE interantional conference on intelligent processing systems, Beijing, China (pp. 468-471).

24. Will, M. (2010). Integrating Smallholders into Global Supply Chains. Eschborn: Deutsche Gesellschaft für Technische Zusammenarbeit.

\section{Contact information}

Ing. Daniel Dédina, Ing. Petra Šánová Ph.D.

Czech University of Life Sciences Prague, Faculty of Economics and Management

Department of Trade and Finance

Kamýcká 129, 16521 Prague 6 - Suchdol

E-mail:dedina@pef.czu.cz,sanova@pef.czu.cz. 